\title{
Corrigendum
}

\section{Viability and stress protection of chronic lymphoid leukemia cells involves overactivation of mitochondrial phosphoSTAT3Ser $_{727}$}

C Capron, K Jondeau, L Casetti, V Jalbert, C Costa, E Verhoeyen, JM Massé, P Coppo, MC Béné, P Bourdoncle, E Cramer-Bordé and I Dusanter-Fourt

Cell Death and Disease (2015) 6, e1627; doi:10.1038/cddis.2014.596; published online 29 January 2015

Correction to: Cell Death and Disease (2014) 5, e1451; doi:10.1038/cddis.2014.393; published online 9 October 2014

Since the publication of this paper it has been noted that E Verhoeyen name was misspelt.
The corrected article appears online together with this corrigendum. The authors would like to apologize for any inconvenience this may have caused. 